\title{
A STUDY OF THE TYPE OF ANTIMICROBIAL ACTION OF NOVEL COMPOUNDS SYNTHESIZED FROM SUBSTITUTED BENZAMINOINDOLES
}

\author{
Stepanenko IS ${ }^{1 \otimes}$, Yamashkin SA², Kostina YuA ${ }^{1}$, Slastnikov ED ${ }^{1}$, Batarsheva $A A^{1}$
}

${ }^{1}$ Institute of Medicine, National Research Mordovia State University, Saransk, Russia

${ }^{2}$ Evseviev Mordovia State Institute of Pedagogy, Saranks, Russia

\begin{abstract}
The antimicrobial activity of novel compounds is tested by determining the minimum inhibitory concentration of the agent in question and investigating a few other parameters, including the type of antimicrobial action the drug exhibits. The aim of this study was to determine the type of antimicrobial action of the compounds synthesized from the substituted benzaminoindoles. The strain of Staphylococcus aureus ATCC 6538-P was briefly exposed to the compounds with laboratory codes 5D, 7D, HD, and S3. Bacterial growth was evaluated macroscopically under transmitted light. Additionally, photoelectric colorimetry was applied to monitor changes in the optical density of the culture medium. The minimum inhibitory concentrations of the studied compounds delayed bacterial growth for $2-3$ days and had a bacteriostatic effect on S. aureus.
\end{abstract}

Keywords: benzaminoindole, pyrroloquinoline, antimicrobial activity, antimicrobial activity type

Author contribution: Stepanenko IS conducted the experiment and analyzed its results; Yamashkin SA helped to design the experiment and synthesized the tested compounds; Kostina YuA analyzed the results of the experiment and wrote the article; Batarsheva AA and Slastnikov ED conducted the experiment.

Correspondence should be addressed: Irina S. Stepanenko

Ulianova 26, Saranks, 430032; ymahkina@mail.ru

Received: 21.11.2018 Accepted: 07.04.2019 Published online: 21.04.2019

DOI: $10.24075 / \mathrm{brsmu} .2019 .030$

\section{ИЗУЧЕНИЕ ТИПА ПРОТИВОМИКРОБНОГО ДЕЙСТВИЯ НОВЫХ СОЕДИНЕНИЙ, СИНТЕЗИРОВАННЫХ НА ОСНОВЕ ЗАМЕЩЕННЫХ БЕНЗАМИНОИНДОЛОВ}

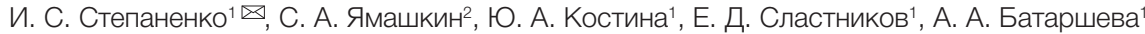

${ }^{1}$ Медицинский институт, Национальный исследовательский Мордовский государственный университет имени Н. П. Огарёва, Саранск, Россия

${ }^{2}$ Мордовский государственный педагогический институт имени М. Е. Евсевьева, Саранск, Россия

\begin{abstract}
Исследование противомикробной активности новых соединений включает изучение как минимальной подавляющей концентрации вещества, так и других показателей, в том числе - определение типа противомикробного действия. Целью работы было определить тип противомикробного действия новых соединений, синтезированных на основе замещенных бензаминоиндолов. Тип противомикробного действия определяли при воздействии исследуемых соединений с лабораторными шифрами 5D, 7D, HD и S3 в коротких экспозициях с использованием тест-штамма микроорганизма Staphylococcus aureus ATCC 6538-P. Рост микроорганизмов в присутствии исследуемых соединений определяли невооруженным глазом в проходящем свете и по изменению оптической плотности культуральной среды фотоколориметрически. Исследуемые соединения задерживали рост тест-штамма S. aureus в течение 2-3 и более суток и оказывали бактериостатическое действие в минимальных подавляющих концентрациях.
\end{abstract}

Ключевые слова: бензаминоиндолы, пирролохинолоны, противомикробная активность, тип противомикробного действия

Информация о вкладе авторов: И. С. Степаненко - участие в реализации экперимента, анализ полученных результатов; С. А. Ямашкин - синтез тестируемых соединений и консультирование по идее исследования; Ю. А. Костина - разработка дизайна статьи и анализ полученных результатов; А. А. Батаршева и Е. Д. Сластников - участие в реализации эксперимента.

Для корреспонденции: Ирина Семеновна Степаненко ул. Ульянова, д. 26, г. Саранск, 430032; ymahkina@mail.ru

Статья получена: 21.11.2018 Статья принята к печати: 07.04.2019 Опубликована онлайн: 21.04.2019

DOI: $10.24075 /$ vrgmu.2019.030

For centuries humanity has been fighting a battle against infectious diseases. Discovery of antimicrobial agents was a crucial milestone in treating and eliminating infections, but it also yielded understanding that bacteria have mechanisms promoting resistance to antibiotics [1-3]. Today, drug resistance in bacteria is a mounting concern. Research into the mechanisms underlying this phenomenon is fundamentally important for developing novel approaches to countering bacterial infections $[4,5]$. Resistance to a wide range of drugs seen in major clinically important microorganisms is a global threat $[6,7]$.

Microbiological surveillance conducted over the past few years has revealed an alarming increase in the number of multidrug-resistant bacterial strains. For example, in comparison with methicillin-susceptible strains, methicillinresistant $S$. aureus do not respond to gentamicin, clindamycin, rifampicin, tetracycline, chloramphenicol, ceftaroline, ciprofloxacin, and erythromycin more frequently; $P$. aeruginosa are resistant to cephalosporins, such as cefepime and ceftazidime, and piperacillin-tazobactam, imipenem, and meropenem; Enterobacteriaceae are resistant to at least three classic antibiotics, such as cefotaxime, ceftazidime, cefepime, aztreonam, etc. [8-10].

The search for and the development of novel antimicrobial agents are crucial for overcoming antibiotic resistance. The need for highly effective and safe antibacterial agents has been emphasized by the government of the Russian Federation [11].

Previously, we synthesized a few indolilamides and pyrroloquinolines from substituted 4-, 5-, 6-, 7-aminoindoles that representing the compounds, which contain cyclic or noncyclic $N$-(indolyl)amides and pyrroloquinolines, exhibit antimicrobial activity against gram-positive and gram-negative microorganisms [12-14].

This study sought to identify the type of antimicrobial activity exhibited by the novel compounds synthesized from substituted aminoindoles. 


\section{METHODS}

The type of antimicrobial action of the synthesized compounds was tested on the test strain of Staphylococcus aureus ATCC 6538-P from the Museum of Live Cultures (State Research Center for Applied Microbiology \& Biotechnology). The microorganisms were exposed to the studied compounds for different time periods at room temperature as described in [15]. The compounds were diluted to a number of different concentrations in the physiological saline and then poured into test tubes (1 $\mathrm{ml}$ per tube). The control tubes did not contain the studied compounds. The microorganisms were suspended in the physiological saline; $1 \mathrm{ml}$ of the resulting suspension was added to each test tube (a final concentration of $1.5 \cdot 10^{8} \mathrm{CFU} / \mathrm{ml}$ ). At this concentration, the turbidity of the bacterial suspension was 0.5 McFarland $[16,17]$. Turbidity was measured using a commercial kit (Sensititre; UK). The optical density of the suspension was determined spectrophotometrically. The bacterial suspension was prepared from a colony grown on slant agar for $24 \mathrm{~h}$. One hundred $\mu \mathrm{l}$ of the physiological solution containing bacteria and one of the studied compounds were pipetted into the tubes filled with $1 \mathrm{ml}$ of a Mueller Hinton broth (MHB) (M391; HiMedia Laboratories Pvt. limited; India) after 5, $10,15,30,60,120$, and 240 min following the preparation of the bacterial suspension. By varying the time of the exposure to a fixed concentration of a studied agent, one can assess the potential and actual effects of the latter, including the effect produced by a minimum inhibitory concentration or its dynamics over time. The properties of antimicrobial compounds can change depending on the medium used and the bacteria themselves [15].

The final concentration of $S$. aureus in the suspension was approximately $5 \cdot 10^{5} \mathrm{CFU} / \mathrm{ml}$ in each test tube. The following concentrations of the synthesized compounds were tested: $25 \mu \mathrm{g} / \mathrm{ml}$ for the cyclic amide 5D, $125 \mu \mathrm{g} / \mathrm{ml}$ for the cyclic amide 7D, $62.5 \mu \mathrm{g} / \mathrm{ml}$ for the amide S3, $59 \mu \mathrm{g} / \mathrm{ml}$ for the cyclic amide $\mathrm{HD}$, and $1 \mu \mathrm{g} / \mathrm{ml}$ for azithromycin [11-13]. Azithromycin chosen for comparison is a classic drug with a bacteriostatic effect; its $\mathrm{MIC}_{90}$ for $S$. aureus is $0.01-2 \mu \mathrm{g} / \mathrm{ml}$ [18]. The test tubes were placed into an incubator and left there for 5 days at $37{ }^{\circ} \mathrm{C}$. The growth of the microorganisms was regularly monitored by examining the tubes macroscopically under transmitted light. Additionally, the optical density of the culture media was measured using a photoelectric colorimeter Apel AP-101 (Energopromavtomatika; Russia). The measurements were performed in $1 \mathrm{ml}$ sterile cuvettes at $600 \mathrm{~nm}$ wavelength. The optical density of the microorganisms cultured in the presence of an antimicrobial compound was compared to the optical density of the microorganisms cultured in the absence of thereof. In total, 4 series of experiments were carried out.

The compounds tested in this work were derived from substituted 4-, 6- and 7-aminoindoles. Their structural formulas are provided below.

1. The cyclic amide with the laboratory code $5 \mathrm{D}$ is a derivative of the substituted 4-amino-2-phenylindole 4-hydroxy-8phenyl-4-(trifluoromethyl)-1,3,4,7-tetrahydro-2H-pyrrolo[2,3-h] quinoline-2-on

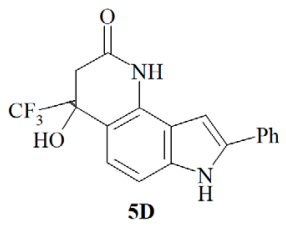

2. The noncyclic amide with the laboratory code S3 is a derivative of substituted 6-aminoindole:
$N$-(1,5-dimethyl-2-phenyl-1H-indole-6-yl)-4,4,4-trifluoro-3oxobutanamide<smiles>Cc1cc2cc(-c3ccccc3)n(C)c2cc1NC(=O)C(F)(F)F</smiles>

S3

3. The cyclic amide with the laboratory code $7 \mathrm{D}$ is a derivative of substituted 6-aminoindole: 9-hydroxy-5-methyl-2phenyl-9-(trifluoromethyl)-1,6,8,9-tetrahydro-7H-pyrrolo[2,3-f] quinoline-7-on<smiles>Cc1cc2cc(-c3ccccc3)[nH]c2c2c1NC(=O)CC2(O)C(F)(F)F</smiles>

4. The cyclic amide with the laboratory code HD is a derivative of substituted 7-aminoindole 6-hydroxy-2,3dimethyl-6-(trifluoromethyl)-1,6,7,9-tetrahydro-8H-pyrrolo[3,2-h] quinoline-8-on<smiles>Cc1[nH]c2c3c(ccc2c1C)C(O)(C(F)(F)F)CC(=O)N3</smiles>

The names for the studied compounds were generated by ACD/LABS Name Generator MarvinSketch 4.7.7.0. (ChemAxon Ltd.; Hungary) according to the IUPAC nomenclature. The structural formulas of the compounds were drawn in ISIS Draw 2.4. (MDL Information Systems; USA).

The obtained data were processed using the analysis of variance. Significance of differences was measured by Student's $t$-test [16].

\section{RESULTS}

Bacterial growth was observed when the optical density $(D)$ of the culture media exceeded 0.21 . The culture medium used as a negative control $\left(5 \cdot 10^{5} \mathrm{CFU} / \mathrm{ml}\right)$ was stored in a refrigerator and had $D=0.003$.

In the control tubes, bacterial growth was visible to the unaided eye $24 \mathrm{~h}$ following inoculation (Fig. 1). The optical density of the culture medium ( 0.26 and above) was also indicative of bacterial growth after $24 \mathrm{~h}$ of incubation (Table). After two days of incubation, $D$ reached 0.39; after 3 days, 0.51; after 4 days, 0.56; after 5 days, it was 0.6. Summing up, the bacterial mass increased by 50\%, 30\%, 9\%, and 7\% after 2, 3, 4 and 5 days of incubation, respectively (Fig. 2). A decline in growth rates can be explained by the depletion of nutrients in the culture medium.

Azithromycin inhibited the growth of $S$. aureus for 3 days. After 4 days of culture in the presence of azithromycin taken at its $\mathrm{MIC}$, visible bacterial growth was noticed macroscopically under transmitted light (Fig. 3). The optical density of the culture medium started to increase after 2 days of incubation (see Table). The $D$ value of the culture medium samples with azithromycin differed significantly from that of the control $(p<0.05)$. After 4 days of culture, the optical density of the culture medium increased to $0.23-0.25$, relative to its initial value, but 
bacterial growth still was significantly delayed throughout the experiment in comparison with the control samples. Delayed growth, which became noticeable only after day 4, suggests the absence of a bactericidal effect. At the minimum inhibitory concentration, azithromycin delays bacterial growth and has a bacteriostatic effect.

During the first $24 \mathrm{~h}$ of incubation, no visible growth was observed under transmitted light in the bacterial cultures exposed to the cyclic amide HD. After 2 days of incubation, the situation did not change. After 3 days, turbidity appeared in all the cultures exposed to the HD compound. The optical density of the samples measured $24 \mathrm{~h}$ after inoculation suggests the inhibition of $S$. aureus growth following exposure to the HD compound (Table; Fig. 4). After 2 days of incubation, this cyclic amide significantly inhibited bacterial growth $(p<0.05)$. Throughout the entire experiment, the optical density of the samples containing HD at the minimum inhibitory concentration was lower than that of the control samples. This means that

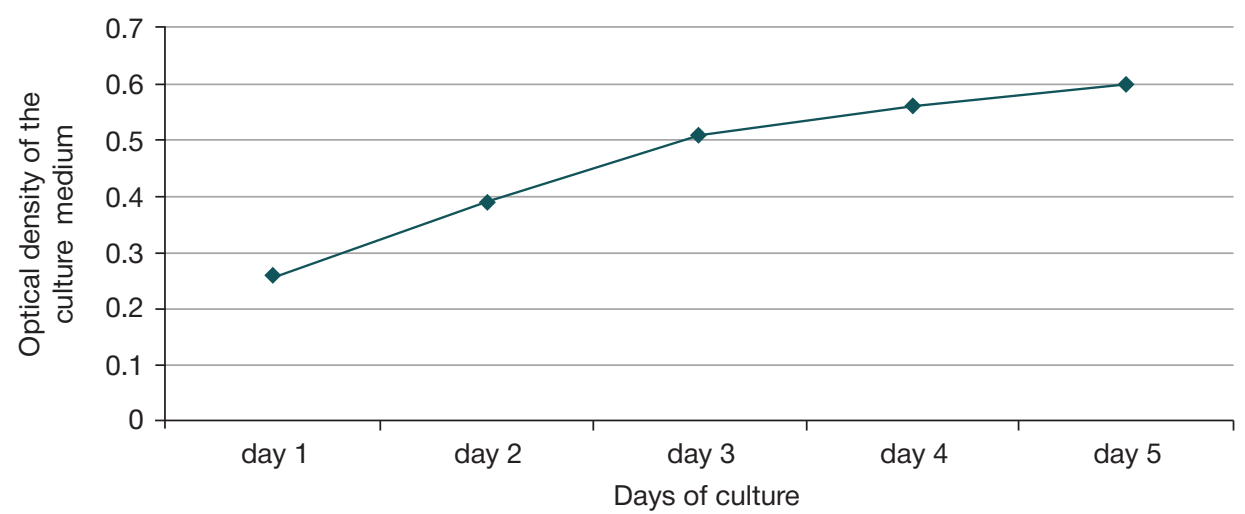

Fig. 1. The optical density of the culture medium with S. aureus ATCC 6538-P throughout 5 days of culture

Table. The growth of S. aureus ATCC 6538-P that studied by the optical density of the culture medium

\begin{tabular}{|c|c|c|c|c|c|c|c|c|c|}
\hline \multicolumn{10}{|c|}{ Exposure time } \\
\hline $\begin{array}{c}\text { Days of } \\
\text { measurements }\end{array}$ & Control & Compounds & $5 \mathrm{~min}$ & $10 \mathrm{~min}$ & $5 \mathrm{~min}$ & $30 \mathrm{~min}$ & $1 \mathrm{~h}$ & $2 \mathrm{~h}$ & $4 \mathrm{~h}$ \\
\hline \multirow{6}{*}{ Day 1} & \multirow{6}{*}{$0.26 \pm 0.03$} & Control & $0.22 \pm 0.01$ & $0.22 \pm 0.02$ & $0.25 \pm 0.04$ & $0.26 \pm 0.02$ & $0.23 \pm 0.05$ & $0.27 \pm 0.03$ & $0.25 \pm 0.02$ \\
\hline & & Azithromycin & $0.05 \pm 0.01^{*}$ & $0.05 \pm 0.01^{*}$ & $0.05 \pm 0.01^{*}$ & $0.05 \pm 0.01^{*}$ & $0.07 \pm 0.03^{\star}$ & $0.07 \pm 0.02^{*}$ & $0.06 \pm 0.01^{*}$ \\
\hline & & HD & $0.07 \pm 0.01^{*}$ & $0.07 \pm 0.02^{*}$ & $0.07 \pm 0.01^{*}$ & $0.08 \pm 0.03^{*}$ & $0.07 \pm 0.01^{*}$ & $0.06 \pm 0.02^{\star}$ & $0.05 \pm 0.001^{*}$ \\
\hline & & S3 & $0.12 \pm 0.02^{*}$ & $0.12 \pm 0.02^{*}$ & $0.10 \pm 0.01^{*}$ & $0.10 \pm 0.02^{*}$ & $0.09 \pm 0.03^{*}$ & $0.09 \pm 0.02^{*}$ & $0.09 \pm 0.02^{\star}$ \\
\hline & & 7D & $0.07 \pm 0.02^{*}$ & $0.07 \pm 0.02^{*}$ & $0.07 \pm 0.01^{*}$ & $0.08 \pm 0.02^{*}$ & $0.06 \pm 0.01^{*}$ & $0.06 \pm 0.01^{*}$ & $0.06 \pm 0.01^{*}$ \\
\hline & & $5 \mathrm{D}$ & $0.010 \pm 0.001^{*}$ & $0.010 \pm 0.001^{*}$ & $0.010 \pm 0.001^{*}$ & $0.010 \pm 0.003^{\star}$ & $0.010 \pm 0.001^{*}$ & $0.010 \pm 0.001^{*}$ & $0.010 \pm 0.002^{*}$ \\
\hline \multirow{6}{*}{ Day 2} & \multirow{6}{*}{$0.39 \pm 0.06$} & Control & $0.38 \pm 0.07$ & $0.38 \pm 0.09$ & $0.38 \pm 0.12$ & $0.37 \pm 0.08$ & $0.43 \pm 0.09$ & $0.39 \pm 0.04$ & $0.44 \pm 0.01$ \\
\hline & & Azithromycin & $0.09 \pm 0.06^{*}$ & $0.09 \pm 0.05^{*}$ & $0.12 \pm 0.04^{*}$ & $0.15 \pm 0.02^{*}$ & $0.15 \pm 0.01^{*}$ & $0.15 \pm 0.04^{*}$ & $0.11 \pm 0.02^{\star}$ \\
\hline & & HD & $0.18 \pm 0.04^{*}$ & $0.18 \pm 0.02^{*}$ & $0.15 \pm 0.03^{*}$ & $0.14 \pm 0.03^{*}$ & $0.09 \pm 0.01^{*}$ & $0.08 \pm 0.01^{*}$ & $0.07 \pm 0.02^{*}$ \\
\hline & & S3 & $0.25 \pm 0.02$ & $0.27 \pm 0.02$ & $0.24 \pm 0.03$ & $0.20 \pm 0.01^{*}$ & $0.19 \pm 0.03^{\star}$ & $0.20 \pm 0.01^{*}$ & $0.20 \pm 0.01^{*}$ \\
\hline & & 7D & $0.15 \pm 0.04^{*}$ & $0.15 \pm 0.02^{*}$ & $0.14 \pm 0.03^{*}$ & $0.19 \pm 0.04^{*}$ & $0.15 \pm 0.02^{*}$ & $0.15 \pm 0.01^{*}$ & $0.13 \pm 0.03^{\star}$ \\
\hline & & $5 \mathrm{D}$ & $0.011 \pm 0.002^{*}$ & $0.012 \pm 0.001^{*}$ & $0.012 \pm 0.002^{*}$ & $0.011 \pm 0.002^{*}$ & $0.011 \pm 0.001^{*}$ & $0.011 \pm 0.003^{\star}$ & $0.011 \pm 0.002^{*}$ \\
\hline \multirow{6}{*}{ Day 3} & \multirow{6}{*}{$0.51 \pm 0.05$} & Control & $0.45 \pm 0.02$ & $0.45 \pm 0.04$ & $0.48 \pm 0.02$ & $0.49 \pm 0.08$ & $0.51 \pm 0.03$ & $0.46 \pm 0.02$ & $0.51 \pm 0.01$ \\
\hline & & Azithromycin & $0.13 \pm 0.07^{\star}$ & $0.13 \pm 0.05^{\star}$ & $0.17 \pm 0.02^{*}$ & $0.20 \pm 0.01^{*}$ & $0.20 \pm 0.01^{*}$ & $0.19 \pm 0.02^{\star}$ & $0.18 \pm 0.02^{*}$ \\
\hline & & HD & $0.28 \pm 0.11$ & $0.28 \pm 0.08$ & $0.28 \pm 0.02$ & $0.24 \pm 0.05^{*}$ & $0.22 \pm 0.03^{*}$ & $0.21 \pm 0.04^{*}$ & $0.23 \pm 0.02^{\star}$ \\
\hline & & S3 & $0.32 \pm 0.1$ & $0.32 \pm 0.07$ & $0.34 \pm 0.04$ & $0.29 \pm 0.5$ & $0.29 \pm 0.04$ & $0.27 \pm 0.05$ & $0.26 \pm 0.03$ \\
\hline & & $7 \mathrm{D}$ & $0.18 \pm 0.03^{*}$ & $0.18 \pm 0.02^{*}$ & $0.17 \pm 0.01^{*}$ & $0.25 \pm 0.04$ & $0.20 \pm 0.01^{*}$ & $0.19 \pm 0.01^{\star}$ & $0.18 \pm 0.01^{*}$ \\
\hline & & $5 \mathrm{D}$ & $0.014 \pm 0.002^{\star}$ & $0.013 \pm 0.003^{\star}$ & $0.014 \pm 0.003^{*}$ & $0.02 \pm 0.007^{\star}$ & $0.014 \pm 0.002^{\star}$ & $0.02 \pm 0.002^{*}$ & $0.02 \pm 0.002^{\star}$ \\
\hline \multirow{6}{*}{ Day 4} & \multirow{6}{*}{$0.56 \pm 0.02$} & Control & $0.53 \pm 0.01$ & $0.53 \pm 0.03$ & $0.56 \pm 0.03$ & $0.56 \pm 0.01$ & $0.58 \pm 0.01$ & $0.54 \pm 0.01$ & $0.57 \pm 0.01$ \\
\hline & & Azithromycin & $0.24 \pm 0.05^{\star}$ & $0.25 \pm 0.03^{*}$ & $0.27 \pm 0.07$ & $0.33 \pm 0.03$ & $0.34 \pm 0.02$ & $0.25 \pm 0.03$ & $0.23 \pm 0.03^{\star}$ \\
\hline & & $\mathrm{HD}$ & $0.35 \pm 0.09$ & $0.35 \pm 0.12$ & $0.36 \pm 0.09$ & $0.36 \pm 0.10$ & $0.32 \pm 0.07$ & $0.36 \pm 0.09$ & $0.30 \pm 0.06$ \\
\hline & & S3 & $0.42 \pm 0.03$ & $0.42 \pm 0.04$ & $0.39 \pm 0.02$ & $0.36 \pm 0.03$ & $0.35 \pm 0.06$ & $0.35 \pm 0.04$ & $0.33 \pm 0.04$ \\
\hline & & 7D & $0.27 \pm 0.02$ & $0.27 \pm 0.04$ & $0.27 \pm 0.06$ & $0.33 \pm 0.03$ & $0.33 \pm 0.04$ & $0.25 \pm 0.03$ & $0.23 \pm 0.01^{*}$ \\
\hline & & $5 \mathrm{D}$ & $0.03 \pm 0.007^{\star}$ & $0.03 \pm 0.008^{\star}$ & $0.03 \pm 0.003^{*}$ & $0.04 \pm 0.011^{*}$ & $0.07 \pm 0.013^{\star}$ & $0.07 \pm 0.01^{*}$ & $0.09 \pm 0.01^{*}$ \\
\hline \multirow{6}{*}{ Day 5} & \multirow{6}{*}{$0.60 \pm 0.02$} & Control & $0.54 \pm 0.03$ & $0.54 \pm 0.05$ & $0.57 \pm 0.03$ & $0.57 \pm 0.01$ & $0.59 \pm 0.01$ & $0.55 \pm 0.04$ & $0.58 \pm 0.03$ \\
\hline & & Azithromycin & $0.25 \pm 0.05^{\star}$ & $0.26 \pm 0.02^{*}$ & $0.28 \pm 0.09$ & $0.38 \pm 0.1$ & $0.36 \pm 0.06$ & $0.26 \pm 0.02^{\star}$ & $0.25 \pm 0.01^{*}$ \\
\hline & & HD & $0.43 \pm 0.05$ & $0.43 \pm 0.09$ & $0.43 \pm 0.06$ & $0.53 \pm 0.05$ & $0.43 \pm 0.09$ & $0.46 \pm 0.04$ & $0.37 \pm 0.9$ \\
\hline & & S3 & $0.43 \pm 0.06$ & $0.43 \pm 0.05$ & $0.40 \pm 0.13$ & $0.37 \pm 0.11$ & $0.36 \pm 0.07$ & $0.35 \pm 0.04$ & $0.35 \pm 0.03$ \\
\hline & & $7 \mathrm{D}$ & $0.31 \pm 0.12$ & $0.31 \pm 0.09$ & $0.31 \pm 0.04$ & $0.42 \pm 0.05$ & $0.35 \pm 0.02$ & $0.31 \pm 0.03$ & $0.25 \pm 0.02^{*}$ \\
\hline & & $5 \mathrm{D}$ & $0.04 \pm 0.009^{*}$ & $0.04 \pm 0.01^{*}$ & $0.06 \pm 0.012^{*}$ & $0.07 \pm 0.011^{*}$ & $0.08 \pm 0.002^{\star}$ & $0.09 \pm 0.01^{\star}$ & $0.11 \pm 0.01^{\star}$ \\
\hline
\end{tabular}

Note: * - differences from the control samples are significant at $p<0.05$. 
MIC of the HD compound delays bacterial growth and has a bacteriostatic effect.

On day 1 of incubation, no visible growth was observed under transmitted light in the samples exposed to the S3 compound. After two days of incubation, there was visible growth in the tubes containing cultures exposed to amide S3 for 5, 10 and $15 \mathrm{~min}$; no visible macroscopic growth was observed in the remaining tubes. On day 3 , turbidity was noticed in the tubes. The S3 amide significantly delayed bacterial growth on days 1 and 2 of culture $(p<0.05)$ (Table; Fig. 5). In the following few days, the rates of $D$ growth demonstrated a gradual decline in comparison with the control samples. A 2-day delay in the bacterial growth suggested the absence of a bactericidal effect. Thus, the S3 compound used at the minimum inhibitory concentration delays bacterial growth and has a bacteriostatic effect.

The cultures exposed to the 7D compound demonstrated no visible growth under transmitted light during the first $24 \mathrm{~h}$ of incubation. After 2 days of culture, the situation did not change. After 3 days of culture, turbidity was noticed in the colonies exposed to the 7D compound for 30 min. After 4 days, turbidity became macroscopically visible in all the cultures from this series of samples. The optical density of the samples exposed to the 7D compound was decreasing significantly for 3 days following the onset of incubation, as compared to the controls
(Table; Fig. 6). Throughout the experiment, bacterial growth was significantly delayed in the samples exposed to the 7D compound. Thus, the MIC of the cyclic amide 7D delays bacterial growth and has a bacteriostatic effect.

Throughout the experiment, no bacterial growth was noticed under transmitted light in the colonies exposed to the compound 5D. The optical density of the inoculated culture medium indicated inhibition of the tested $S$. aureus strain throughout 5 days of incubation (Table; Fig. 7). The $D$ value of the samples was significantly different from that of the control tubes $(p<0.05)$ throughout the experiment, but still tended to increase. Perhaps, the concentration of the 5D compound in the culture was close to bactericidal. We conclude that the cyclic amide 5D delays bacterial growth and has a bacteriostatic effect.

Summing up, the cyclic amide 5D derived from 4-aminophenylindole, the amide S3 and the cyclic amide 7D derived from substituted 6-aminoindoles, as well as the cyclic amide $\mathrm{HD}$ derived from substituted 7-aminoindoles, delayed the growth of S. aureus ATCC 6538-P for at least 1 day. Apart from the S3 compound, the studied compounds continued to inhibit bacterial growth on day 2 of culture. Visible bacterial growth and an increase in the optical density of the culture medium were observed after $48 \mathrm{~h}$ of incubation in the tubes exposed to the compound S3 for 5, 10 and 15 min. After 3

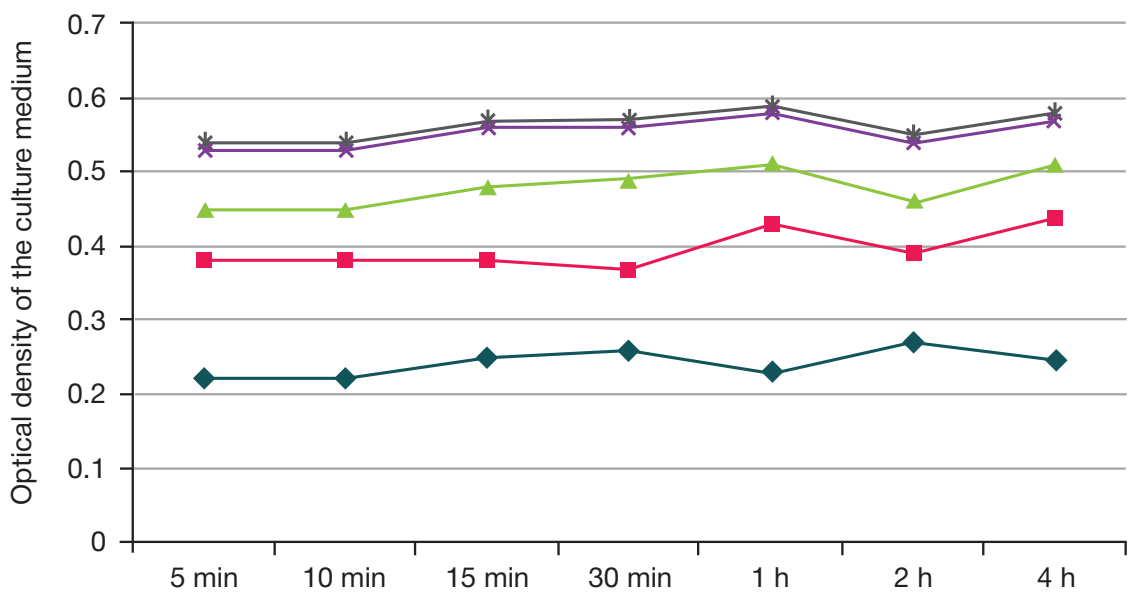

Duration of exposure to the physiological saline

day 1

- - day 2

$\therefore$ day 3

$*$ day 4

$\rightarrow$ day 5

Fig. 2. The optical density of the culture medium with $S$. aureus ATCC 6538-P after exposure in the physiological saline during 5 days of culture

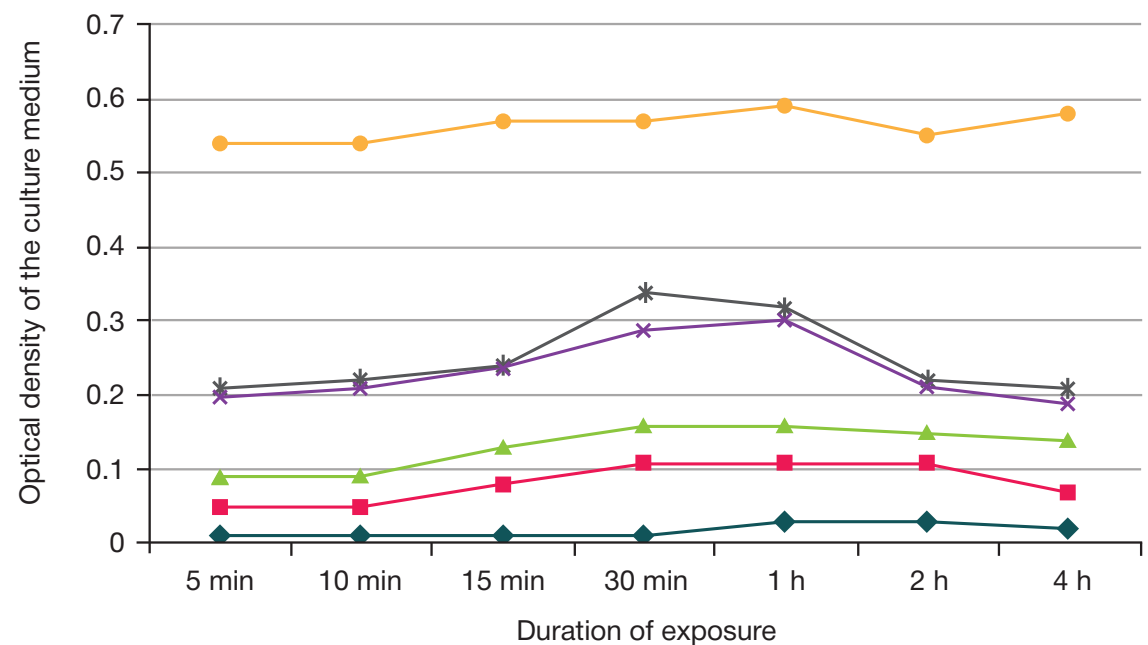

Duration of exposure

$\longrightarrow$ day $1 \quad \longrightarrow$ day $2 \quad \rightarrow$ day $3 \quad *$ day $4 \quad *$ day $5 \quad \longrightarrow$ day 5 control

Fig. 3. The optical density of the culture medium with $S$. aureus ATCC 6538-P after exposure to azithromycin 


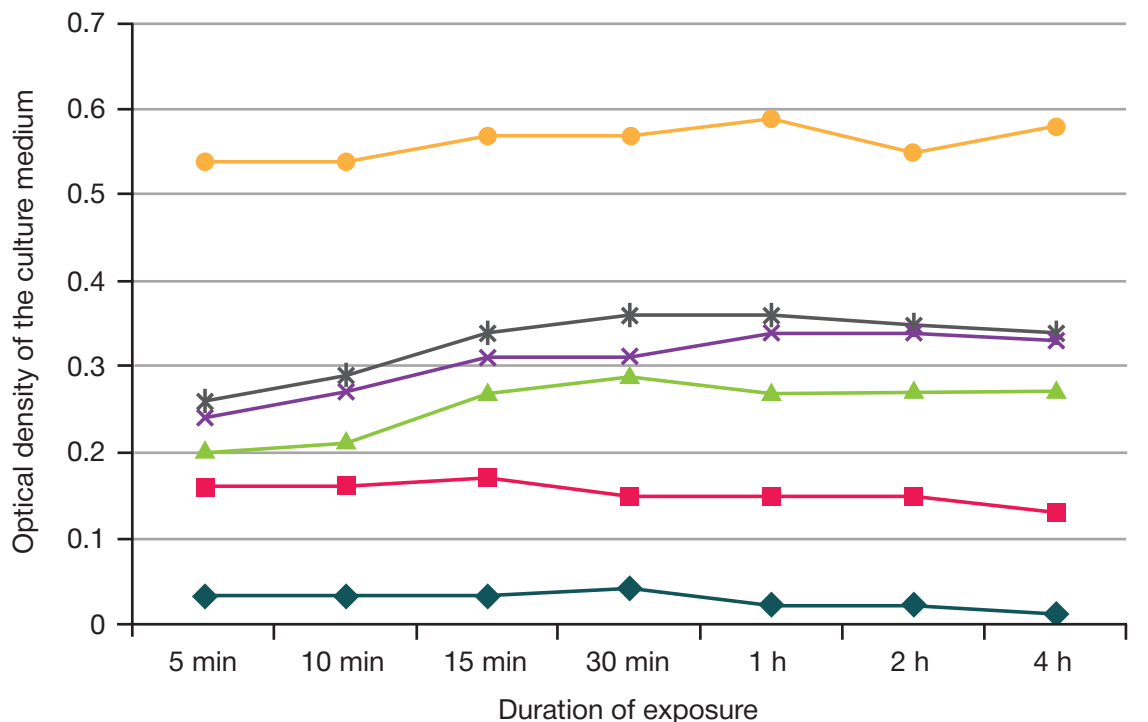

$\multimap$ day $1 \quad \longrightarrow$ day $2 \longrightarrow$ day $3 \quad *$ day $4 \quad *$ day $5 \quad \longrightarrow$ day 5 control

Fig. 4. The optical density of the culture medium with $S$. aureus ATCC 6538-P after exposure to the compound HD

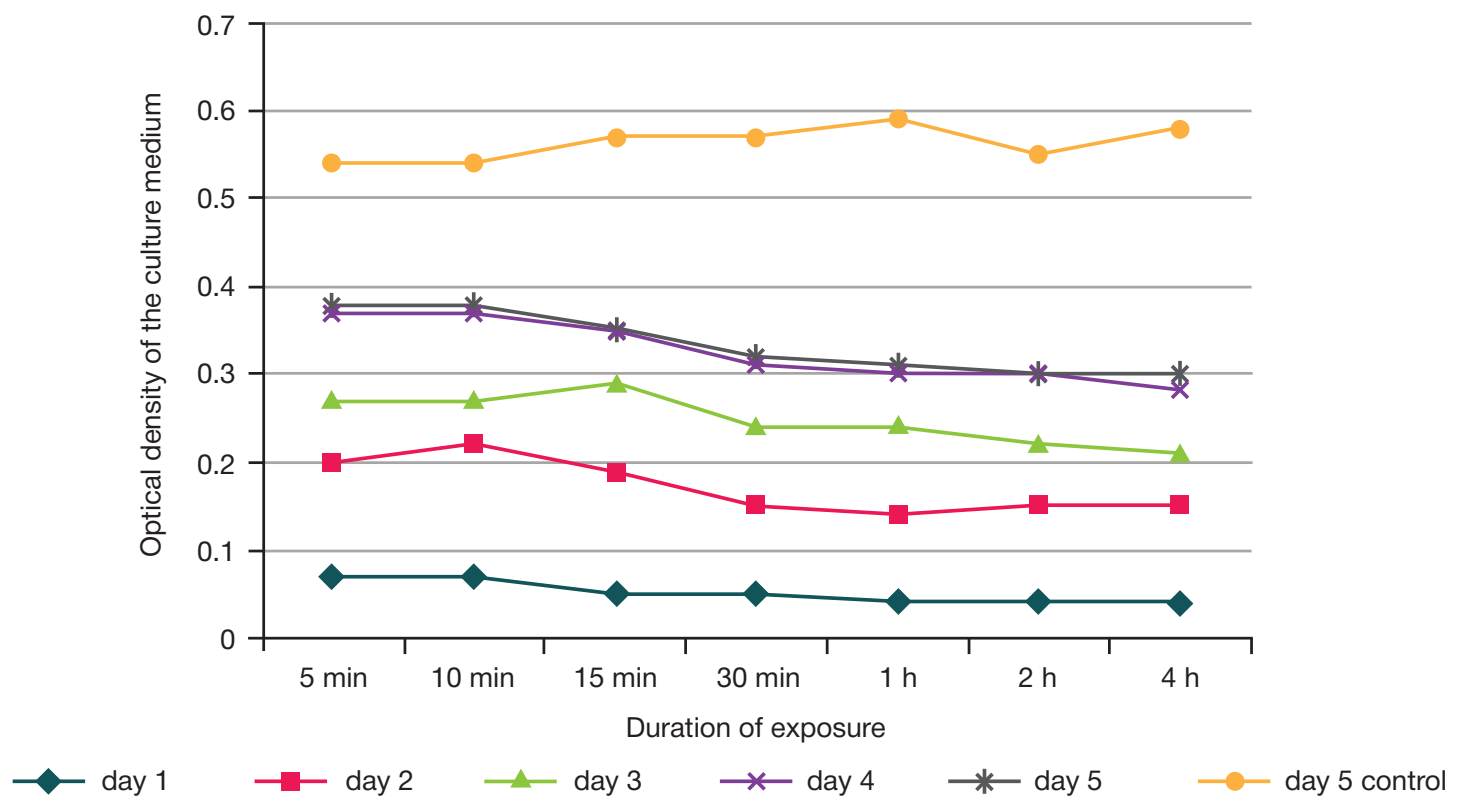

Fig. 5. The optical density of the culture medium with $S$. aureus ATCC 6538-P after exposure to the compound S3

days of incubation, visible bacterial growth was observed in all the tubes exposed to the compounds HD and S3. After 4 days of incubation, visible bacterial growth was observed in the samples exposed to the compound 7D. No visible growth of $S$. aureus ATCC 6538- $P$ was noticed throughout 5 days of the experiment in the samples exposed to the compound 5D, although the optical density dynamics suggested an increase in the bacterial population.

The type of antimicrobial action of the studied compounds synthesized from substituted 4-, 6-, 7-aminoindoles that have the strongest antimicrobial effect is comparable to that of azithromycin, a classic antibiotic with a bacteriostatic effect.

\section{DISCUSSION}

Over the past decades, the chemistry of indoles and their derivatives has been in the focus of experimental research. Indoles are basic components of many natural and synthetic compounds that possess a physiological activity, such as tryptophan or serotonin, a biogenic amine. Aminoindoles with an amino group in the benzene ring arouse particular interest. Like any other aromatic amines, these compounds have a lot of derivatives with an amino group component [12-13]. Previously, we studied interactions between $\beta$-dioxycompounds and substituted aminoindoles with different positions of the amino group in the benzene ring. We developed methods for the synthesis of 16 aminoindoles and their 32 derivatives indolilamides, enamines and pyrroloquinolines. Their MIC and spectra of antimicrobial activity were also determined.

While studying a novel antimicrobial compound, it is important to determine its minimum inhibitory concentration, identify the type of antimicrobial activity or its range, explore the mechanism underlying the biological effect, etc. The type of antimicrobial activity is usually determined by comparing $\mathrm{MIC}$ and minimum bactericidal concentrations (MBC); such method allows researchers to only arbitrarily classify a new compound based on its effect on the bacterial cell [16]. The method applied in this study involves the use of brief exposures to the compound in question [15]; it allowed us not only to identify the type of antimicrobial activity but also to prove that 


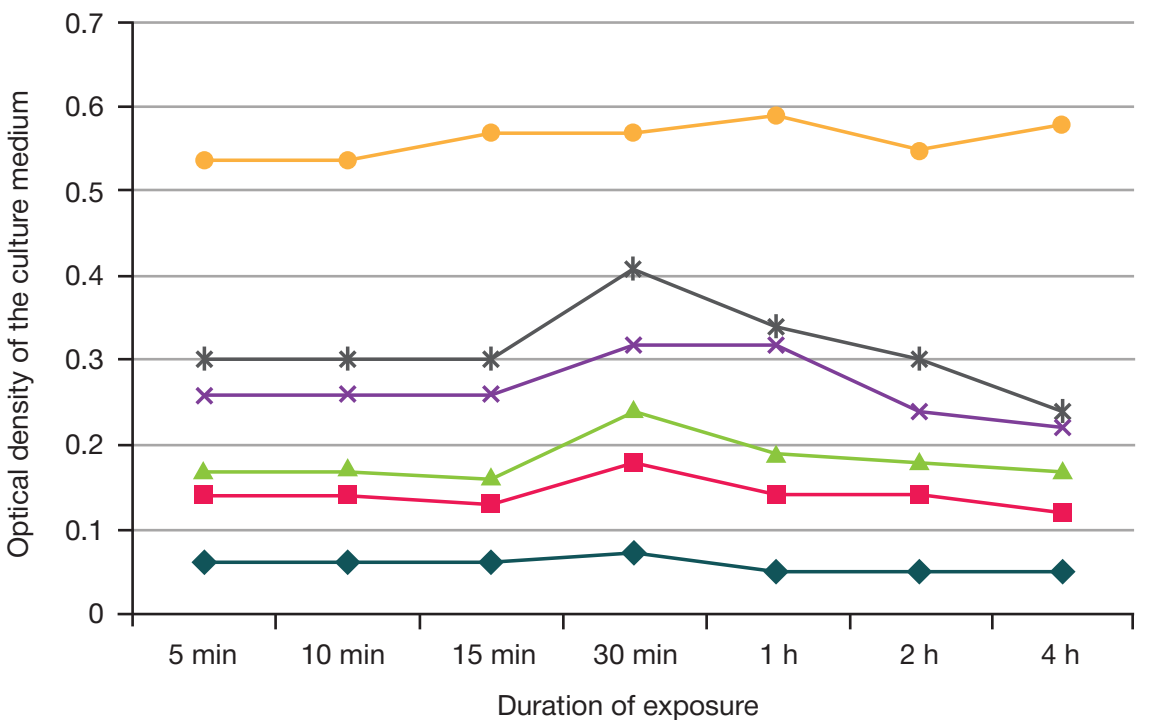

$\multimap$ day $1 \quad \longrightarrow$ day $2 \longrightarrow$ day $3 \quad *$ day $4 \quad *$ day $5 \quad \longrightarrow$ day 5 control

Fig. 6. The optical density of the culture medium with S. aureus ATCC 6538-P after exposure to the compound 7D

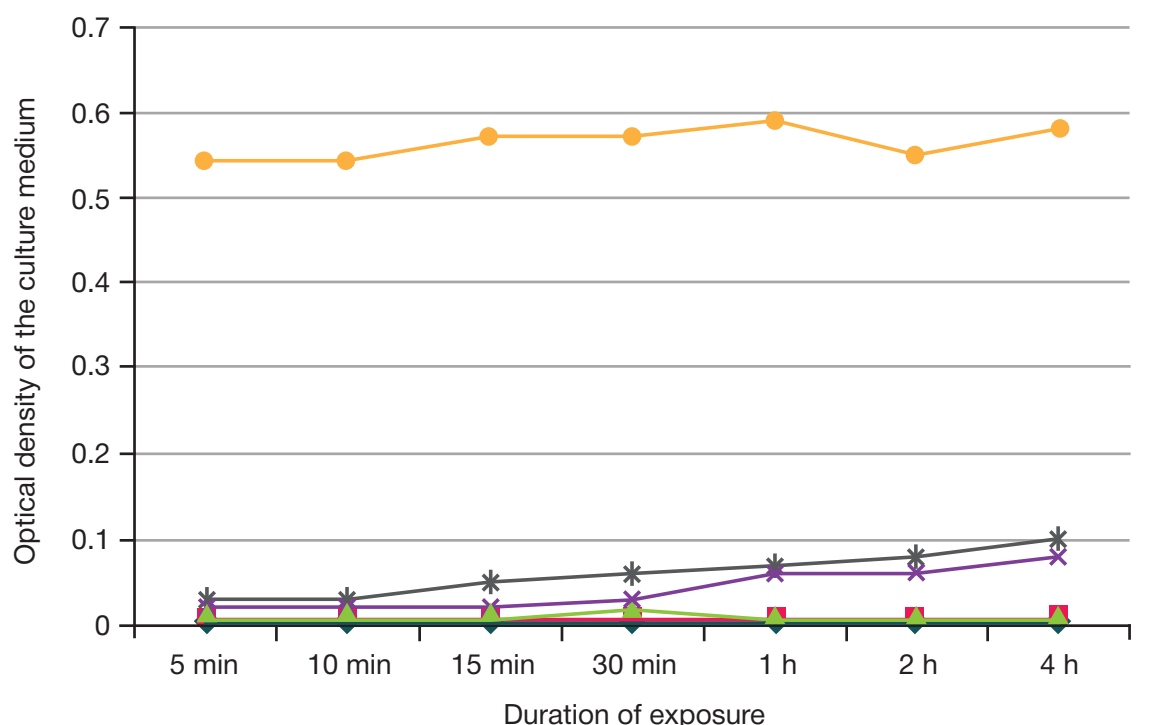

Duration of exposure

Fig. 7. The optical density of the culture medium with S. aureus ATCC 6538-P after exposure to the compound 5D

the synthesized compounds retain their antimicrobial properties regardless of the duration of exposure, the properties of the medium or the activity of microorganisms themselves. Throughout the experiment, the growth of $S$. aureus ATCC 6538- $P$ was generally delayed following exposure to any of the studied compounds, although the optical density of the bacterial population may have been increasing. Considering the proven bacteriostatic effect of the compounds used at minimum inhibitory concentrations, we hypothesize that the mechanism underlying the antimicrobial effect of 4-, 6-, 7-aminoindole derivatives does not involve a possible effect on the cell wall or the cytoplasmic membrane that eventually leads to cell death. Perhaps, the studied compounds have a certain effect on the DNA of the bacterial cell (DNA damage or any additional mechanism that is not accompanied by DNA breaks) or on protein synthesis. In the next step, we are planning to study the mechanisms underlying the antimicrobial activity of 4-, 6-, 7-aminoindole derivatives.

\section{CONCLUSIONS}

We have proven that derivatives of substituted benzaminoindoles used at minimum inhibitory concentrations produce a bacteriostatic effect and delay the growth of $S$. aureus ATCC $6538-P$. Our findings encourage us to continue research into the synthetic derivatives of 4-, 6-, 7-aminoindoles and the feasibility of their application as antimicrobial agents in clinical practice. 
1. Parhizgari N, Gouya MM, Mostafavi E. Emerging and re-emerging infectious diseases in Iran. Iranian Journal of Microbiology. 2017; 9 (3): 122-42.

2. Yokoyama M, Stevens E, Laabei M, Bacon L, Heesom K, Bayliss S et al. Epistasis analysis uncovers hidden antibiotic resistanceassociated fitness costs hampering the evolution of MRSA. Genome Biology. 2018; 19 (1): 94.

3. Kumarasamy KK, Toleman MA, Walsh TR, Bagaria J, Butt F, Balakrishnan $\mathrm{R}$ et al. Emergence of a new antibiotic resistance mechanism in India, Pakistan, and the UK: a molecular, biological, and epidemiological study. The Lancet Infectious Diseases. 2010; 10 (9): 597-602.

4. McKeegan KS, Borges-Walmsley MI, Walmsley AR. Microbial and viral drug resistance mechanisms. Trends in Microbiology. 2002; (10): 8-14.

5. Savjani JK, Gajjar AK, Savjani KT. Mechanisms of resistance: useful tool to design antibacterial agents for drug - resistant bacteria. Mini-Reviews in Medicinal Chemistry. 2009; 9 (2): 194-205.

6. Yadav N, Dubey A, Shukla S, Saini CP, Gupta G, Priyadarshini R et al. Graphene Oxide-Coated Surface: Inhibition of Bacterial Biofilm Formation due to Specific Surface-Interface Interactions. ACS Omega. 2017; 2 (7): 3070-82.

7. Obayiuwana A, Ogunjobi M, Yang M, Ibekwe M. Characterization of Bacterial Communities and Their Antibiotic Resistance Profiles in Wastewaters Obtained from Pharmaceutical Facilities in Lagos and Ogun States. Nigeria International Journal of Environmental Research and Public Health. 2018; 15 (7): 1365.

8. Kozlov RS. Antibiotic resistance of gram-positive pathogens of complicated intra-abdominal infections in Russia. Clinical microbiology and antimicrobial chemotherapy. 2015; 17 (3): 227-34.

9. Romanov AV. Antibiotic resistance of nosocomial strains of Staphylococcus aureus in hospitals in Russia: results of the Marathon 2013-2014 multicenter epidemiological study. Clinical microbiology and antimicrobial chemotherapy. 2017; 19 (1): 57-62.

10. Sukhorukova MV. Antibiotic resistance of nosocomial
Enterobacteriaceae strains in hospitals in Russia: the results of the Marathon 2013-2014 multicenter epidemiological study. Clinical microbiology and anti-microbial chemotherapy. 2017; 19 (1): 49-56.

11. Rasporyazheniye Pravitel'stva RF ot 25 sentyabrya $2017 \mathrm{~g}$. № 2045-r «O strategii preduprezhdeniya rasprostraneniya antimikrobnoy rezistentnosti v RF na period do 2030 g.». Available from: https://www.garant.ru/products/ipo/prime/doc/71677266/. Russian.

12. Alyamkina EA, Stepanenko IS, Yamashkin SA, Yurovskaya MA. Soedineniya s potencial'noj antimikrobnoj aktivnost'yu na osnove 4-amino-2-fenilindola. Vestnik Moskovskogo universiteta. 2016; 57 (6): 410-7. Russian.

13. Alyamkina EA, Yamashkin SA, Stepanenko IS, Yurovskaya MA. 4-amino-2-phenylindole-based compounds with potential antibacterial activity. Moscow University Chemistry Bulletin. 2017; 72 (1): 24-8.

14. Stepanenko IS. A new group of compounds derived from 4-, 5-, 6- and 7-aminoindoles with antimicrobial activity. Research Results in Pharmacology. 2018; 4 (3): 17-26.

15. Pershin GN, redaktor. Prakticheskoe rukovodstvo. Metody ehksperimental'noj himioterapii. M.: Medicina, 1971; 541 s. Russian.

16. Mironov AN, Bunyatyan ND, Vasilyev AN, Verstakova OL, Zhuravleva V, Lepakhin VK, i dr. Rukovodstvo po provedeniju doklinicheskih issledovanij lekarstvennyh sredstv. M.: Grif i K, 2012; 944 s. Russian.

17. Opredelenie chuvstvitel'nosti mikroorganizmov $k$ antibakterial'nym preparatam. Metodicheskie ukazanija MUK 4.2.1890-04. Klinicheskaja mikrobiologija i antimikrobnaja himioterapija. 2004; 6 (4): 303-402. Russian.

18. Kozlov RS, Sukhorukova MV, Eidelstein MV, Ivanchik NV, Skleenova EYu, Timokhova AV, et al. Determination of the sensitivity of microorganisms to antimicrobial drugs: clinical recommendations. Smolensk: Interregional Association of Clinical Microbiology and Antimicrobial Chemotherapy. 2018; 206 p.

\section{Литература}

1. Parhizgari N, Gouya MM, Mostafavi E. Emerging and re-emerging infectious diseases in Iran. Iranian Journal of Microbiology. 2017; 9 (3): 122-42.

2. Yokoyama M, Stevens E, Laabei M, Bacon L, Heesom K, Bayliss S et al. Epistasis analysis uncovers hidden antibiotic resistanceassociated fitness costs hampering the evolution of MRSA Genome Biology. 2018; 19 (1): 94

3. Kumarasamy KK, Toleman MA, Walsh TR, Bagaria J, Butt F, Balakrishnan $\mathrm{R}$ et al. Emergence of a new antibiotic resistance mechanism in India, Pakistan, and the UK: a molecular, biological, and epidemiological study. The Lancet Infectious Diseases. 2010; 10 (9): 597-602.

4. McKeegan KS, Borges-Walmsley MI, Walmsley AR. Microbial and viral drug resistance mechanisms. Trends in Microbiology. 2002; (10): 8-14

5. Savjani JK, Gajjar AK, Savjani KT. Mechanisms of resistance: useful tool to design antibacterial agents for drug - resistant bacteria. Mini-Reviews in Medicinal Chemistry. 2009; 9 (2): 194-205.

6. Yadav N, Dubey A, Shukla S, Saini CP, Gupta G, Priyadarshini R et al. Graphene Oxide-Coated Surface: Inhibition of Bacterial Biofilm Formation due to Specific Surface-Interface Interactions. ACS Omega. 2017; 2 (7): 3070-82.

7. Obayiuwana A, Ogunjobi M, Yang M, Ibekwe M. Characterization of Bacterial Communities and Their Antibiotic Resistance Profiles in Wastewaters Obtained from Pharmaceutical Facilities in Lagos and Ogun States. Nigeria International Journal of Environmental Research and Public Health. 2018; 15 (7): 1365.

8. Козлов Р. С. Антибиотикорезистентность грамположительных возбудителей осложненных интраабдоминальных инфекций в России. Клиническая микробиология и антимикробная химиотерапия. 2015; 17 (3): 227-34.
9. Романов А. В. Антибиотикорезистентность нозокомиальных штаммов Staphylococcus aureus в стационарах России: результаты многоцентрового эпидемиологического исследования «Марафон» 2013-2014. Клиническая микробиология и антимикробная химиотерапия. 2017; 19 (1): 57-62.

10. Сухорукова М. В. Антибиотикорезистентность нозокомиальных штаммов Enterobacteriaceae в стационарах России: результаты многоцентрового эпидемиологического исследования «Марафон» 2013-2014. Клиническая микробиология и антимикробная химиотерапия. 2017; 19 (1): 49-56.

11. Распоряжение Правительства РФ от 25 сентября 2017 г. № 2045-р «О стратегии предупреждения распространения антимикробной резистентности в РФ на период до 2030 г.». Доступно по ссылке: https://www.garant.ru/products/ipo/prime/ doc/71677266/.

12. Алямкина Е. А., Степаненко И. С., Ямашкин С. А., Юровская М. А. Соединения с потенциальной антимикробной активностью на основе 4-амино-2-фенилиндола. Вестник Московского университета. 2016; 57 (6): 410-17.

13. Alyamkina EA, Yamashkin SA, Stepanenko IS, Yurovskaya MA. 4-amino-2-phenylindole-based compounds with potential antibacterial activity. Moscow University Chemistry Bulletin. 2017; 72 (1): 24-8.

14. Stepanenko IS. A new group of compounds derived from 4-, 5-, 6- and 7-aminoindoles with antimicrobial activity. Research Results in Pharmacology. 2018; 4 (3): 17-26.

15. Першин Г. Н. редактор. Практическое руководство. Методы экспериментальной химиотерапии. М.: Медицина, 1971; 541 с.

16. Миронов А. Н., Бунятян Н. Д., Васильев А. Н., Верстакова О. Л., Журавлева М. В., Лепахин В. К. и др. Руководство по 


\section{ОРИГИНАЛЬНОЕ ИССЛЕДОВАНИЕ І МИКРОБИОЛОГИЯ}

проведению доклинических исследований лекарственных средств. М.: Гриф и К, 2012; 944 с.

17. Определение чувствительности микроорганизмов к антибактериальным препаратам. Методические указания МУК 4.2.1890-04. Клиническая микробиология и антимикробная химиотерапия. 2004; 6 (4): 303-402.
18. Козлов Р. С., Сухорукова М. В., Эйдельштейн М. В., Иванчик Н. В., Склеенова Е. Ю., Тимохова А. В. и др. Определение чувствительности микроорганизмов $\mathrm{k}$ антимикробным препаратам: клинические рекомендации Смоленск: Межрегиональная ассоциация по клинической микробиологии и антимикробной химиотерапии. 2018; 206 с. 